\title{
Problem on Nuclear Theory of Cultivation Science of Crops
}

\author{
Peizhan Tian \\ Centre of Germplasm Introduction and Crop Breeding of Jilin Province, Changchun, China \\ Email: peizhantian@163.com
}

Received 25 March 2016; accepted 8 April 2016; published 12 April 2016

Copyright (C) 2016 by author and OALib.

This work is licensed under the Creative Commons Attribution International License (CC BY). http://creativecommons.org/licenses/by/4.0/

(c) (i) Open Access

\section{Abstract}

This paper considered that theory system explaining and demonstrating all of cultivation practice and alone having attribute of cultivation science of crops could not be formed for Cultivation Science of Crops of China. Due to influence of scientific concept of western scholars, theory of this applying subject only stopped on level of point obtaining from contacts in general terms among things, lacked highly summarizing and abstraction, but contents of this subject were on basis of big agriculture conception, ecological agriculture, it embodied idea that recognizing crop production only from long-term interests, higher layer, bigger range, including handing well relationship both among all of ecological systems and between planting industry and animal husbandry, could well resolve problem of food. Putting forward new concept of Cultivation Science of Crops, it was science researching contradiction movement among yield factors of crop (high-yielding) community and regularity of regulation and control technique. This definition protruded internal essence and feature of this subject and its difference with near subjects. Expounded relative nucleus theories and concrete contents of improved cultivation science of crops depend on needs of development of ecological agriculture, practices of crop production and existing problems, compared them with present teaching material of agricultural college. Problem on development of cultivation science of crops was finally discussed.

\section{Keywords}

Crop, Cultivation Science, Nucleus Theory

Subject Areas: Agricultural Science, Plant Science

\section{Introduction}

High unity of opposition between theory and practice was basic law developing science. Continuously developing cultivation practice and increasing crop yield must set up theory system of cultivation science of crops, two 
complemented each other, promoted each other and raised together. Then how were present situations of theories of cultivation science of crops? These were whether corresponding or not? How to recognize evaluate and raise them, obviously had important significance for anew creating theory, raising practice level and promoting development of production of crops.

Any subject had its own study object, study object of each subject must possess attribute that could not be replaced by other subjects. For example, physiology was a subject studying regularity of growth and development of plant, cultivation science of crops was a subject (or science) studying contradictions and contradiction movements among yield factors of community and technique regularity of regulation and control for yield factors of community. But present teaching materials of cultivation science of crops existed a large number of phenomenon that contents belonging to physiology of plant were put into cultivation science of crop to act as nuclear theory, contents concerning contradiction movements among yield factors of community and technique regularity of regulation and control for them were not very full and it made theory system of cultivation science of crops very weak and not complete, and could not fully explain and illustrate rich technology practice at present.

Object of this paper was expounding study contents and nuclear theory system of cultivation science of crops on basis of present situation and problem of cultivation science of crops, practices in process of crop production and some theory viewpoints concerning cultivation science of crops.

\section{Present Situation and Problem of Cultivation Science of Crops}

At present common definition for cultivation science of crops in textbook in agricultural college in China was that "it was a branch of agronomy, its main task was studying regular of growth and development and its relationship with environment condition, relative technique of regular and control, and a subject of synthetic technology. Studying and applying for it had important significance for enhancing quantity and quality of crop products, reducing production cost, raising labor productivity and economic benefit. Cultivation science of crop was studying science for growth and development, forming regular of yield and quantity and their relationship with environment condition, exploring theory, method, and technique of high-yielding, superior quantity, high benefit and continued development through cultivation management, regular and control of growth, optimization decisions, cultivation science of crops was most both essential and important composition part in agronomy. Crop production was process of combination of natural reproduction with economical reproduction, and had strict regionalism" [1] [2].

Cultivation Science of Crops was a science in China, since it was a science or subject, it should have general attribute of subject, should have both practice and theory, two were complement and promotion each other, forming theory system of cultivation science of crop having Chinese feature. But because crop subject continued mainly academic idea and point from the western scholars, theory system that could explain and demonstrate all of cultivation practice and alone had attribute of cultivation science of crops could not be formed for Cultivation Science of Crops of China, except main theory was still using content of other basis subjects (physiology of plant and botany etc.), mainly was narrative of technology or practice. Crop Science as grade-2 subjects had not subordinate subjects, which were to say crop breeding and cultivation being not sciences, this also was a illustration of low level of theory system of cultivation science of crops, simultaneously was consistent with point only being art not sciences of some western scholars [3].

Only subject of relative crop production was agronomy in America. Agronomy specialty of Agricultural College of Kansas State University explanted for agronomy: “Agronomy was a subject studying plant, soil and their roles to environment, through applying subject principle agronomists mainly studied how to raise grain yield in the world, protect natural environment, reasonably apply valuably resources of soil and water. Mankind was faced with a huge challenge that how to harmonize contradiction between protecting the globe resources and satisfying humanity living requirement increasing day by day”. Obviously, this was on basis of big agriculture conception in more extensive scope. This conception of big agriculture was essentially ecological agriculture, with plant and soil as nucleus to set up ecological system in globe environment and ecological agriculture system. It embodied idea that recognizing crop production only from long-term interests, higher layer, bigger range, including handing well relationship both among all of ecological systems and between planting industry and animal husbandry, could well resolve problem of food [4]. This point was defect of crop science of China, also academy idea reason that could not well handle problem of relationship between planting industry and animal husbandry, soil problem and rapid worsening of soil quality. 
On scientific concept, some western scholars thought there was not scientific theory and there was applying technique for applying subjects, must use basic subject theory as its scientific principle, this was identical with that applying subjects were called as arts or technology and only had engineering or engineering system, no subject theory and could not be called as science. Applying subjects were called as subjects, but not science and there were not itself scientific theory, this was self-contradictory, also a method of theory losing contact with practice Therefore their theory of applying subject only stopped on level of point obtaining from contacts in general terms among things, lacked highly summarizing and abstraction and effectively using each methods of study to form scientific theory or theory system. Until present there was not a microcosm of theory of cultivation science of crops as China.

Study task of cultivation science of crops of China was increasing yield and quantity of China, in a narrow range, only less agriculture scope. It included not contents of soil, increasing grain yield in the World, protecting natural environment, reasonably using resources of soil and water, also resolving contradiction between limited resources and humanity subsistence etc. great problem in the World.

Cultivation science of crops in China also had not itself theory system, mainly used theory of other subjects of basis, for example basically included regularity of growth and development of plant and relationships with environment, regulation and control for growth etc that belonged to plant physiology, these became most important theory basis of cultivation science of crops [1] [2].

Peoples regarded soil as cheap and inexhaustible resource, not a ecological system having itself development law. Soil was basis of planting industry and animal husbandry, there was not development of soil ecology system and not planting industry and animal husbandry, so contents concerning importance of ecological system of soil, principle and technique protecting fertilizer and water of soil etc should be expounded in cultivation science of crops of China. Also should discuss list problems: relationships each other among main ecological systems, influence of major meteorological disasters to crop production, guiding by ecology to developing agriculture and science and technology of agriculture [5].

\section{Process of Crop Production and Study Content of Cultivation Science of Crops}

Along with growth and development of crops from preparation of seed, fertilizer and other production resources to each of growth ranges of crop, farmers managed for individual of crops, but they thought always yield per unit area, for obtaining higher yield of community, they worked hard for well disposing relationship between individual and community from starting to end. This should be starting point of cultivation science of crops and most essential theory basis.

Since cultivation science of crops was a subject, it should have itself theory and practice that had unique feature and could not be replaced by other subjects. Most essentially speaking, Cultivation Science of Crops was science researching contradiction movement among yield factors of crop (high-yielding) community and regularity of regulation and control technique. This definition protruded internal essence and feature of this subject and its difference with near subjects.

On basis of this definition, relationship between individual and community should be firstly researched and determined, secondly on basis of different production condition (mainly were soil fertility, amount of applying fertilizer and varieties) determined change regularity of reasonable density and became a nucleus theory of cultivation science of crops, because reasonable density was premise well controlling contradiction between vegetable growth and reproductive growth, this premise was not unreasonable density. Controlling reasonable density was "big control" or "quality control", controlling growth and development of community on basis of reasonable density was "less or quantity control", only like this both high yield and good economic benefit could be obtained.

Variety was an important factor in crop production. In generalness yield production often had opportunity selecting for more varieties and they could give same or very similar yield.

But in creating highest-yielding field selecting for varieties was very strict even only, under this situation in reality selected yield ability of varieties, more exactly speaking selected turning density of variety and turning yield [6]. Because after turning density process of appropriate rare planting on fruitful land often was ignored and applying time and range of super varieties were restricted for example corn. In crop production firstly using fertility of planting land and amount of applying fertilizer reasonable planting density was determined, secondly seeing variety feature accurate amount of sowing and leaving seedlings density.

Problem in below a layer was relationship between reasonable density and plant distribution in field. Under 
premise of certain reasonable density, studying plant distribution (including complex community of two or above crops) in field that could raise utilization efficiency of both light energy and soil fertility.

Planed ideal state often had difference with reality in crop production, for example we demanded reaching number of seedling, number of ear or seed per ear, weight per seed etc. that were unfortunate with realistic situations. Natural conditions unceasingly influenced for crop populations, this required on basis of realistic situation, regularity of growth and development and relationship with outside conditions and gave promoting or controlling measures to reach protect objective to obtain high-yielding. So stages of growth and development of crops and their relationship with external conditions and through what measures to promote or control and their principles should be expounded.

Final, problems of machinery and essential of increasing yield, what was machinery forming yield, should raised recognition for all of increasing techniques, their objectives and essential were enhancing use efficiency of light energy or soil fertility, using this basic principle to study and apply new ways, new measures and new methods of increasing crop yield

\section{Suggestion Improving "Cultivation Science of Crops (Overview)"}

Universally acknowledged fundamentally essential factors of an independent subject were:

1) Study objective or field, unique and irreplaceable study object,

2) Theory system, special conception, principle, proposition, law etc. that formed strictly logical knowledge system,

3) Methodology, production way of subject knowledge [7].

Cultivation science of crops had itself special study field, mainly were relationship between community and individual, contradiction among factors of community yield and its movement, technology regularity of highyielding. These had essential differences compared with plant physiological that mainly researched individual property, regularity of growth and development, process of biological physiology and chemistry. A part contents of plant physiological could become theory basis of cultivation science and breeding science of crops (for example relationships among sink, source and flow), but should not be their most fundamentally nucleus theory in highest layer and guiding role.

Setting up a subject, firstly should follow law of scientific development, combined highly theory with practice, raised technology and experience up to theoretical height, organic combination knowledge or theories of relative subjects to form unique theory system of cultivation science of crops of China.

Setting up theory system of cultivation science of crops must start from analyzing and studying basic contradiction in crop production, contradiction between community and individual, from unity of opposition of yield factors of population, on basis of this researched regularity of development harmonizing each other of these yield factors.

According to this nucleus theory system and reasonably logical relations among all of problems, net system of science knowledge of crops, idea of agricultural ecology playing guiding role for development of agriculture and science and technology of agriculture, influence of above these for crop production, main contents [6] improved cultivation science of crops should be:

Cultivation Science of Crops (Overview)

Introduction: Law of Scientific Development and Net System of Science Knowledge of Crops

Chapter 1 Sunshine Activity, Global Atmosphere Environment, Ecology, Ecological System and Crop Production

Chapter 2 Community and Individual in Crop Production

Chapter 3 Change Regularity of Reasonable Density of Crops

Chapter 4 Evolution of Yield Ability Characteristics of Crop Cultivars

Chapter 5 Distribution of Plant in Field

Chapter 6 High-Yielding Machine: Reasonable Tendency of Growth and Development of Community and Regular and Control for It

Chapter7 Essential Increasing Yield: Uninterruptedly Resolving Contradiction of between Utilization Efficiency of Light Energy and Soil Fertility of Populations.

Usual "Cultivation Science of Crops (Overview)", for example the teaching material of ordinary higher education of national plan in "eleven five" [1], had four parts and twenty three chapters. This teaching material was 
compared with above improved cultivation science of crops.

Contents of all of parts of the teaching material:

1) Basic conception of cultivation science of crops and its forming and feature, origin, dissemination, distribution, utilization of human,

2) Special property of growth and development of crops, organogenesis and its relatively of growth and development etc. basic regularity of growth and development of individual of crops,

3) Basic feature and special property of growth and development of crop community, mutual relations among source sink, flow in dry matter production, structure factors of crop yield, regularities, regulating and control of yield forming and yield potential, quality forming,

4) Relationships between crops and environment, ecological adaptability of crops and regulation action of environment for crop growth.

Above first part had universality, only played role of introduction or preface, this part of contents had not big difference in different teaching material, might have also have not this part. Second part was basic knowledge of growth and development, sixth chapter in improved cultivation science of crops (overview) included cream part of this content as theory basis of technology of promotion and control. In third part, Special property of growth, relationship among sink source flow of crop population to be separated from special property of growth and development of individual was not necessary, relation of unity of opposition between population and individual should not be separated, relative contents should be put in part 2. Structure factors of crop yield should be put in chapter of "change regularity of reasonable density", because contradiction movement of yield structure factors was basic reason and theory basis of change regularity of reasonable density. Yield potential of variety, quantity characteristic and problem of ecological adaptability separately belong to yielding ability theory of variety and adaptability theory of variety, were necessary contents of breeding science of crops. In cultivation science of crops evolution of cultivars in production and change regularity of yield ability and its characteristics should be expounded in order to selecting cultivars to provide theory support.

Cultivation science of crops should also discuss problems of ecological-cultivation, variety-cultivation and ecology of variety, generally narrated principle selecting cultivar under different conditions in different area, not unduly involved nucleus theory that belong to breeding science. Contents concerning regulating and control of environment for growth of crops should put in chapter 6 in improved Cultivation Science of Crops, such could more closely combined theory with practice

Global climate changes and another ecological system had big influence to crop production, specially was relation of unity of opposition between ecological systems of soil and crop, development of ecological system of crops must depend on that of ecological system of soil. Ecological problems in different layers were important for future crop production, so relative problems guiding with agricultural ecology to develop agriculture and science and technology of agriculture [5] should be discussed in first chapter.

If law of scientific development and basis on it forming leading ideal of scientific study, net system of knowledge of crop sciences could be put in introduction and firstly discussed, such subject will be complete and thoughtful.

Length of Improved Cultivation Science of Crops (Overview) could be bigger shorten through above summing up and further arranging.

It was thus clear that "Improved Cultivation Science of Crops" was formed under guiding of thinking having special feature of cultivation science of crops, and reached closed combination of theories with practices. It was not only absorbing essences of relative basis subjects, but also using unity of opposition of internal contradiction of community yield to unify and harmonize these, abstracting and summarizing, anew creating theory system.

\section{Problem of Development Concerning Cultivation Science of Crops}

Due to lacking developing strategy of crop cultivation science that conformed to development law of crop cultivation science, worse realistic production conditions and test field conditions, study on crop cultivation be fallen into difficult position. Creating high-yielding typical model was more and more difficult, lost most basic basis of practice. Realistic production conditions, specially being problem of soil quality yet became most important factor limited of enhancing level of both crop yield and breeding. But peoples still mistook that reasons of lower level production and lower soil fertility level were less applying chemical fertilizer. If amount applying chemical fertilizer was several times in China, yield of crops was yet lower, reason was variety or cultivation technology, further speaking, reason of lower yield was that scientist and technician could not do them duty. Essentially 
more applying chemical fertilizer could not enhance soil quality, oppositely under lower soil quality, applying amount of chemical fertilizer was the more, declining of soil quality the more rapid, forming malignant circle.

So most urgent task of Chinese agriculture was all of production units of planting industry realizing combination of agriculture with animal husbandry or three combination among agriculture, animal husbandry and forestry, more applying chemical fertilizer, realizing straw returning to field, comprehensively and step by step raising basic fertility of planting land and experimental field [5] [6]. Organizing soil was a matter of vital importance for Chinese and a greatly strategic problem of sustainable development of agriculture, also a great policy problem for dignified life of farmers, government should organize, harmonize and fulfill.

On above basis, depending scientific theory or theory system (author suggested theory system and research contents of cultivation science of crops) conforming to development regularity of high-yielding community, laid down long-term strategic development plans of cultivation science of crops and scientifically organized and practiced, under varied ecological conditions and different cultivation systems created conformable high-yielding models, combined them with wide production practice to become technology patterns of massive popularization, at the same time combined with further theory study to enhanced continuously theory level, certainly could promote effective and healthy development of cultivation science crops of China.

\section{Conclusion}

Author guided with law of scientific development, depended on need of development of ecological agriculture, practice of crop production and all problems in crop production, expounded nucleus theories, theory system and concrete study contents of improved cultivation science of crops. Improved Cultivation Science of Crops (Overview) not only had special feature and subject attribute but also reached close combination between theory and practice. It was not only absorbing essences of relative basis subjects, but also using unity of opposition of internal contradiction of community yield to unify and harmonize these, abstracting and summarizing, anew creating theory system. Simultaneously, it included contents setting up agricultural ecology system with plant and soil as nucleus. It embodied correct idea that recognizing crop production only from long-term interests, higher layer, bigger range, including handing well relationship both among all of ecological systems and between planting industry and animal husbandry, could well resolve problem of food.

\section{References}

[1] Cao, W.X. (2011) Cultivation Science of Crops (Overview). Ordinary Higher Education of National Plan in "Eleven Five”. 2nd Edition, Agricultural Science and Technique Publishing House of China, Beijing.

[2] Liu, Z.F. and Huang, H. (2007) Cultivation Science of Crops (Overview). Publishing House of Science and Technology of Agriculture of China, Beijing.

[3] Education Ministry of the People’s Republic of China (2012) Partition of Fields of Disciplines of Conferring Academic Degrees.

[4] Donnelly Kevin, J., et al. (2013) Agronomy, the Teaching Material of Agronomy Specialty. Agronomy College, Kansas State University.

[5] Tian, P.Z. (2014) Theoretical Genetics and Breeding Science of Crops. Science and Technique Publishing House of Jilin, Changchun.

[6] Tian, P.Z. and Wang, G.S. (2011) Philosophical Principle Increasing Crop Yield. Science Publishing House, Changchun.

[7] Zhang, L.X. (1982) Thinking Method Producing Scientific Theories. Shandong People’s Publishing House, Jinan. 